\title{
Implementation of Corporate Social Responsibility in the Ready-Made Garment Industry of Bangladesh in Order to Achieve Sustainable Development Goals: A Study on Bangladeshi Garment Manufacturers
}

\author{
Ummelewara Bristi, Monirul Islam Rajib, Sharmin Shoukat \\ Apparel Manufacturing \& Technology, Knitwear Manufacturing \& Technology, BGMEA University of Fashion \& Technology, \\ Dhaka, Bangladesh \\ Email: ummelewara@buft.edu.bd,monirulislam@buft.edu.bd,sharminshoukat@buft.edu.bd
}

How to cite this paper: Bristi, U., Rajib, M.I. and Shoukat, S. (2020) Implementation of Corporate Social Responsibility in the Ready-Made Garment Industry of Bangladesh in Order to Achieve Sustainable Development Goals: A Study on Bangladeshi Garment Manufacturers. Journal of Textile Science and Technology, 6, 232-246. https://doi.org/10.4236/jtst.2020.64019

Received: March 12, 2020

Accepted: November 24, 2020

Published: November 27, 2020

Copyright $\odot 2020$ by author(s) and Scientific Research Publishing Inc. This work is licensed under the Creative Commons Attribution International License (CC BY 4.0).

http://creativecommons.org/licenses/by/4.0/

\begin{abstract}
The Ready-Made Garment (RMG) sector has played the most momentous role for the economic development of Bangladesh. To achieve the culmination, this labor-intensive industry needs to go through sustainable practices with the adoption of Corporate Social Responsibility (CSR) in its garment manufacturing chain. CSR, being a fast-developing phenomenon in industrial arena, is drawing the attention of world-renowned apparel buyers working with Bangladesh. After a few tragic occurrences, for instance, Rana Plaza collapse \& Tazreen Fashion fire, the reputation of the RMG sector of Bangladesh has been somewhat blemished. Presently, this scenario is being changed since a considerable number of Bangladeshi garment producers have adopted CSR practices spending a huge sum of money. This study shows the current status of sustainable development through the implementation of CSR practices in the RMG industry of Bangladesh.
\end{abstract}

\section{Keywords}

Sustainability, Sustainable Developments Goals, Ready-Made Garments, Corporate Social Responsibility

\section{Introduction}

RMG has been the most contributing part of Bangladesh's economy in the last two decades. Bangladesh holds the 2nd position in terms of the volume of ex- 
ported apparel in the world. The ready-made garment industry of Bangladesh is responsible for bringing about US\$30.61 billion in the fiscal year 2018-2019 which constitutes around $83.49 \%$ of total export earning in that period totaling $15 \%$ of the national GDP in that period [1]. The major buyers are considering Bangladesh as the next China since China is shrinking their apparel business in the recent past [2]. This sector has enabled 4 million of direct workers working in the industry $80 \%$ of whom are rural women [3]. In the last decade, RMG has gained more export, increased foreign exchanges \& more contributions to the country's economy. In the recent past, Bangladesh faced a few major challenges, like, Rana Plaza collapse \& Tazreen Fashion fire. Accord \& Alliance has taken the responsibility to test the structural, fire \& electrical safety of every garment manufacturing unit of the country. Alongside, many garment factories have assumed the necessity of adopting the green and sustainable practices through the adoption of CSR in the total garment manufacturing chain. In this connection, the world top seven out of ten garment manufacturers are from Bangladesh. Though CSR is a novel phenomenon in RMG industry, its growing practice in other areas of the world has made the garment owners of Bangladesh thinking seriously on it. If this timely consideration had not appeared in the conscience of the garment owners, it could pave the way to quick demise of the industry failing to cope up with the rest of the world. Initially, CSR was thought to be an additional cost contributing to the rise in garment final cost curtailing the profit. But later on, the industry could realize its necessity following intense inclination towards CSR. If sustainable development is not implemented by CSR to the factories of Bangladesh soon, it may lose its global market position \& value. Bangladesh will face the demise of the RMG sector sooner or later if they avert CSR.

\section{Objectives of the Study}

The primary objective of this study is to find out:

- The concept of CSR and sustainability in the RMG industry.

- Importance of sustainability to remain competent in the world.

- And study the present scenario of CSR in apparel industry.

\section{Literature Review}

Most of the CSR studies conducted so far have been in the context of developed countries such as Western Europe, the USA, and Australia [4]. Very few studies are available on the CSR practices in the developing countries. All of these studies were carried out in the context of newly industrialized countries such as Malaysia, Singapore, South Africa, Nigeria, and Uganda. Henceforth, very few studies are available on the CSR practices in developing countries [4]. Basically, in the context of Bangladesh we can see the practice has not been found widely in this country [4]. In reality, trade union practices are not perceptible in 4560 RMG factories [5]. Most of the cases garments workers have no freedom in their factories to join union [6]. 
From the daily financial express, it is evident that BEI (Bangladesh Enterprise Institute) in January 2005 launched its CSR center, which has been organizing monthly roundtable discussions to promote CSR in Bangladesh. They designed the key stakeholders to enhance the understanding of CSR. The context of Bangladesh, although a clear understanding about CSR may be absent, there is a volume of philanthropic activities and businesses are eager to adopt CSR practices [7].

From Bangladeshi historical news we found that one of the socking news at least 54 workers were killed and 100 seriously injured when a textile factory burned down in the port city of Chittagong. Many of those killed on badly injured were prevented from escaping because factory guards had locked the main entrance and others get to prevent theft and monitor the 600 worker, mainly young women worker working in the night shift [8]. Industry closure is an important issue in the history of de-industrialization in Bangladesh.

Fire broke out on 24 November 2012, in the Tazreen Fashion factory in the Ashulia district on the outskirts of Dhaka, Bangladesh. At least 117 people were confirmed dead in the fire, and at least 200 were injured, making it the deadliest factory fire in the nation's history. Several steps have been taken after that accident to reduce this type of situation. But we can say if organizations maintain proper safety policy for their employee then this type's deadliest accident can be removed from our industrial arena.

Again, we found another deadliest incident in Bangladesh. 24th April 2013, an eight-story commercial building Rana Plaza collapsed in Savar, a sub-district near Dhaka, the capital of Bangladesh. At least 1125 people died as of 12 May, many people were still missing. It housed a number of separate garment factories employing around 5000 people, several shops, and a bank. Garment's owners as well as the building owner are responsible for this terrible incident. This case shows that CSR is not well exercised matter in this industry [9].

This study incorporates 10 different garment factories in Bangladesh to see how much CSR practices there are. However, this paper tries to find out the above mention objectives. Furthermore, in order to gather general ideas regarding CSR practices in Bangladesh, and to uphold the present scenario of CSR practices among RMG makers comprehensive study was conducted among different stakeholders.

\section{Concept of CSR}

CSR, which was previously referred to as social responsibility (SR) and today some often call it as corporate responsibility (CR) over the years has gained unprecedented momentum in business and public debate and has become a strategic issue crossing the departmental boundaries, and affecting the way in which a company does business [10]. Referring some studies, expressed that there is an impressive history associated with the evolution of the concept of CSR although it is stated that roots of the concepts and implementations could be traced back 
to prehistoric times, generally works on its evolution start with 1950s and 1990s are defined with its popularity and development of similar themes [11]. In the 1990s, an increasing number of corporate social responsibility reports, standards and codes of conduct show the interest for CSR. But asserted that corporate engagement with society, also termed Corporate Social Responsibility (CSR) mired in a definitional debate dating back several decades [12]. One of the earliest definitions seeing CSR since then, the field has evolved assuming different names such as corporate social responsiveness in the 1970s and corporate social performance in the 1980s [13]. This evolution also reflects an increase in awareness in important areas of action and performance that the early definitions had overlooked. The view that until the 1970s, despite regulation and legislation, the business continued largely along an autonomous path, ignoring its critics and listening only to its shareholders, to whom it felt somewhat responsible [14].

Carroll who expressed that CSR has been evolving as early as the 1930s [15]. But Zerk who discussed a more contemporary evolution from the international legal precedents starting visionary employee compensation policies to more complex examples of corporate citizenship in recent years. In his book Zerk, quoted numerous examples of Corporate initiatives that can be categorized as CSR for instance, in 1914 Henry Ford's employees received higher salaries in 8 hour working days, when the industry standard was 9-hour work days, and in 1935 Johnson \& Johnson published a document titled "Try Reality" where the company defined its responsibility towards different groups of society, an initiative that was followed by a publication of a company-wide "Credo" in 1994 that outlined the corporation's ethical and social goals which made it a precursor of many modern Codes of Ethics [16]. The root of CSR has emerged since the industrial revolution era yet the subject is still being in a debatable position until today. It appears to be difficult for researchers to identify or share the common definition, principles or core areas of CSR [17].

Considered that there had been earlier demonstrations of Corporate Citizenship or Corporate Philanthropy that can be considered forms of Social Responsibility in Business, dating from the Pre-medieval period (5000B.C.-550A.D.) to the time where the concept gained social Prominence (1930-1988)? Further narrated that even when present actions of corporate philanthropy before the twentieth century represented isolated efforts; it was not until the advent of the figure of multinational corporations that the discussion on the topic evolved. Up until then, there was no clear idea of whether companies had an inherent responsibility towards society. In 1929 the then Dean of Harvard Business School Walter B. Donham raised the point when he said: "Business has been long centuries before the dawn of history, but business, as we know, is new, new in its broadening scope, new in its social significance [18].

\section{Concept of Sustainability}

Sustainability is one the newest degree that attempts to link social science with 
civic engineering and environmental science with the technology of the future development. Generally, it means improving the present lifestyle. Sustainability is the changing global business environment having emerged as a result of significant concerns about the unintended social, environmental, and economic consequences of rapid population growth, economic growth and consumption of our natural resources. The Brundtland report has the status of being the launching pad for the global agenda on sustainability. That is why the Brundtland report's definition of sustainability is a safe starting point to use as a base: "Sustainable development is the development that meets the needs of the present without compromising the ability of future generations to meet their own needs". In the debate in the West, the Brundtland report is regarded as having put the global environment on the agenda, but one of its great strengths and reasons for its impact was that it connected global environmental issues to the need for global development and reduction of poverty. Until then, there had been a conflict of interest between the rich countries' increasing focus on the environment and the poor countries' focus on poverty. The Brundtland report aligned social sustainability as a necessary element. This is also the reason for it being so positive towards economic growth, as the case is: "What is needed now is a new period of economic growth, a growth that is strong as well as socially and environmentally stable." It is important to bear in mind that sustainability is not a definitive concept. It means that there will always be a political position, either conscious or unconscious, in relation to the choice of development in environment and production. Generally, we distinguish between two concepts of sustainability, so-called "week" and "strong" sustainability.

Sustainability Development Goals (SDG) to be achieved through CSR Practice in the RMG sector in Bangladesh:

SDG Goal 1: No poverty.

SDG Goal 2: Zero hunger.

SDG Goal 3: Good health \& well-being.

SDG Goal 4: Quality education.

SDG Goal 5: Gender equality.

SDG Goal 6: Clean water \& sanitation.

SDG Goal 7: Affordable \& clean energy.

SDG Goal 8: Decent work \& economic growth.

SDG Goal 9: Industry, innovation \& infrastructure.

SDG Goal 10: Reducing inequality.

SDG Goal 11: Sustainable cities \& communities.

SDG Goal 12: Responsible consumption \& production.

SDG Goal 13: Climate action.

SDG Goal 14: Life under water.

SDG Goal 15: Life on land.

SDG Goal 16: Peace, justice \& strong institutions.

SDG Goal 17: Partnerships for the goals. 


\section{Methodology}

To conduct the study, we have selected ten garment factories operating in Bangladesh associated with CSR practices at different degrees in several operational areas. In-depth interviews were taken from the mid \& top management to get the real scenario of those factories. The obtained data have been analyzed, summarized \& presented using different visual tools to reach a conclusion.

\section{Result and Discussion}

\subsection{Companies Consciousness on Manufacturing: Sustainable}

Corporate social responsibility (CSR) has a long convention, particularly in privately-run companies however it truly came refinement in the most recent decade when expansive multinationals started to receive it to exhibit that they were not kidding about conveying a positive social effect on the groups in which they worked.

Figure 1 shows companies' consciousness on sustainable manufacturing where $60 \%$ (6 out of 10) companies are highly conscious on sustainable manufacturing. Some of these 5 companies have sustainable related international latest LEED certificate, ISO 14401:2004 certificate and others certificate and some companies have suitability report and policy, and rest 30\% (3 out of 10) and 10\% (1 out of 10) companies are moderately and somewhat conscious on issues because they have other certificates along with ISO.

This paper work is based on those companies which have at least one international certificate related to sustainable manufacturing. Most of the company have more than one certificate. And these certificates are ISO 14001:2004, LEED, Oeko-Tex, CU certificate, WRAP, OE-100 \& OE-Blended and GOTS. Firms obtained above mentioning certificate because of fulfilling of criteria which related to sustainable manufacturing practice in RMG industry. Figure 3 shows international certificate of surveyed firms. Here environment management system related ISO 14001:20042 certificate is obtained by 60\% (6 out of 10) firms and US green building council provided LEED is obtained by $30 \%$ ( 3 out of 10) firms.

Figure 2 showed that $40 \%$ (4 out of 10) firms take textile related Oeko-Tex

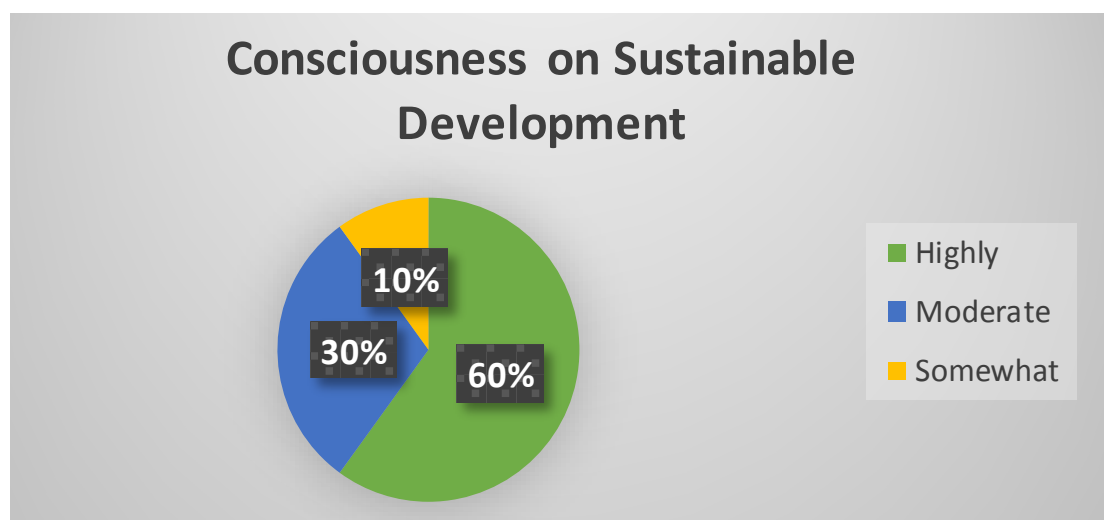

Figure 1. Consciousness on sustainable development. 


\section{International Certificate}

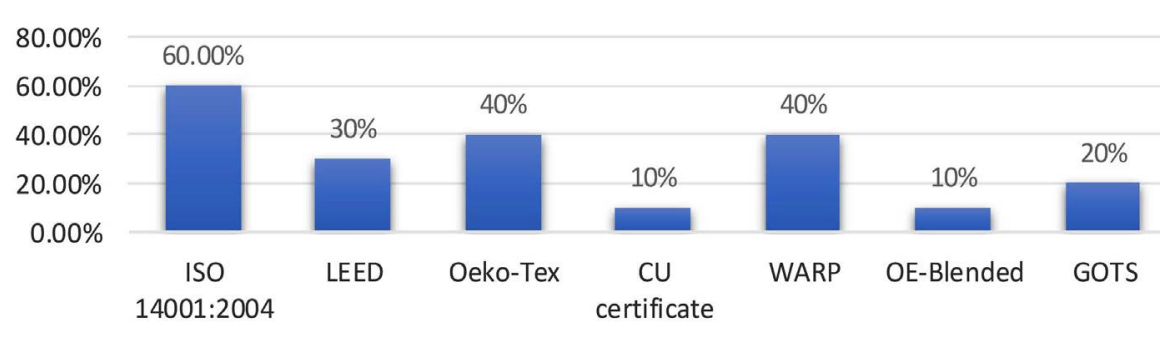

Figure 2. International certificate.

100 standard, 10\% (1 out of 10) CU compliance certificate. This figure further shows that Economy \& Resource Efficiency certificate WRAP is taken by $40 \%$ ( 4 out of 10) firms, OE-Blended 10\% (1 out of 10) and GOTS (global organic textile standard) $20 \%$ ( 2 out of 10 ).

\subsection{Waste Management}

The trash left out after each process of production remains waste. Waste Management is the human control of the collection, treatment and disposal of different wastes (liquid and solid).

Management serves dual purposes by making the industrial operations more competitive as well as protecting the environment. The common waste management process followed by RMG industry in Bangladesh is ETP for treating liquid waste and reusing water for washing toilet as well as sprinkling onto the gardens and plantations, reusing spinning waste, reusing fabric, making organic fertilizer and selling rejected garments to local markets or third parts. The survey result of waste management followed by the RMG selected manufacturers are given in figure:

We see from Figure 3 that $80 \%$ (8 out of 10) manufacturers used Effluent Treatment Plan for treating liquid waste coming from different producing process specially dying section. Also $100 \%$ (10 out of 10) of the companies selling their rejected garments to third party or local markets. $60 \%$ (6 out of 10 ) companies responded that they have used their ETPs treated water as a flash water for their worker toilets. 30\% (3 out of 10) companies reported that they reused their spinning waste as raw materials and organic fertilizer. Organic fertilizer also produced from citizen waste and other natural ingredients which are done by $20 \%$ ( 2 out of 10) companies. Waste management another process is reusing fabric that is adopted by $40 \%$ ( 4 out of 10) companies and this waste are coming from cutting section.

\subsection{Sustainable Manufacturing Process}

This section consists of reduction of energy consumption, usage of renewable energy, reduction of water consumption and reduction of noise pollution practices. 


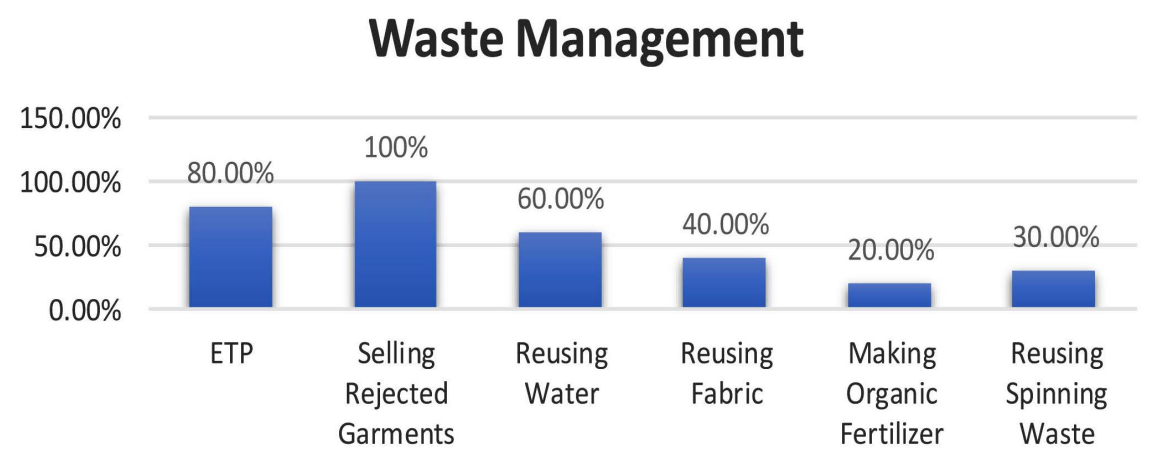

Figure 3. Waste management.

\section{Reduction of Energy Consumption}

According to Figure 4, 100\% (20 out of 20) companies reported that they are using energy efficient LED light instead of T-8 lights and sewing machines fitted with servo motors which are proven as energy efficient. Such initiatives have resulted in the reduction of electricity consumption by $35 \%-40 \%$.

$30 \%$ (3 out of 10) companies claimed that they reused their condensed steam. This heated water is supplier to boiler to produce steam once again which save natural gas. Only $10 \%$ (1 out of 10) used co-generation boiler which also save fuel gas. The natural cooling pads are used by $20 \%$ (2 out of 10) companies instead of air condition or hundreds of ceiling fans that saving electricity. 20\% (2 out of 10) companies claimed that they install dryer exhaust to save gas used in dying unit. Only 10\% (1 out of 10) companies install meters (water flow meter, energy meter, and steam flow meter) to reduce energy consumption.

\subsection{Renewable Energy}

"Renewable energy is defined as energy that is collected from resources which are naturally replenished on a human timescale, such as sunlight, wind, rain, tides, waves, and geothermal heat" [19]. Because of global warming, world is emphasized more on renewable energy. Now a day organization as well as industries tries to convert renewable energy system from traditional system. The surveyed data showed on Figure 5 that $70 \%$ (7 out of 10) companies partially install renewable energy system in their industries and offices and 30\% (3 out of 10) still not take any not take any initiative to install renewable energy system.

Among 10 RMG companies, 30\% (3 out of 10) used turbo ventilation, 60\% (6 out of 10) used solar panel, 20\% (2 out of 10) companies produce biogas form natural wastage and $40 \%$ (4 out of 10) used day light as a renewable energy system for meet up them partial energy demands, which is showed in Figure 6 [20].

\subsection{Reduction of Water Consumption}

$80 \%$ (8 out of 10) companies reported that they reused their process water (ETPs treated) that can save their water consumption. $90 \%$ (9 out of 10) companies used water saving equipment such as servo motors, air dying machine that can save water consumption in RMG industry, as per Figure 7. 


\section{Reduction of Energy Consumption}

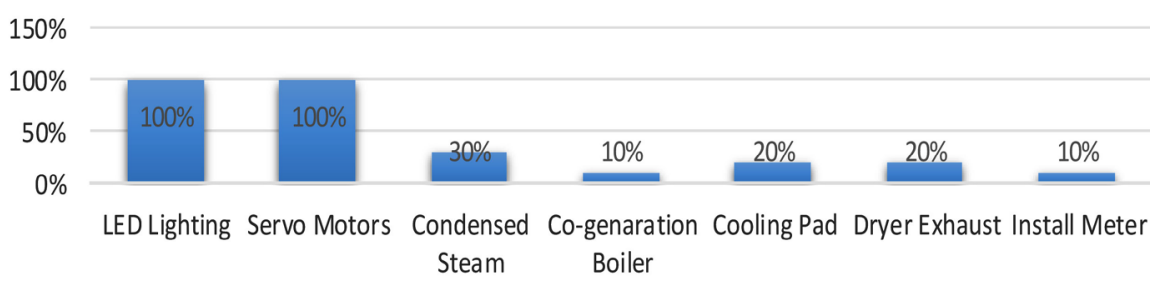

Figure 4. Reduction of energy consumption.

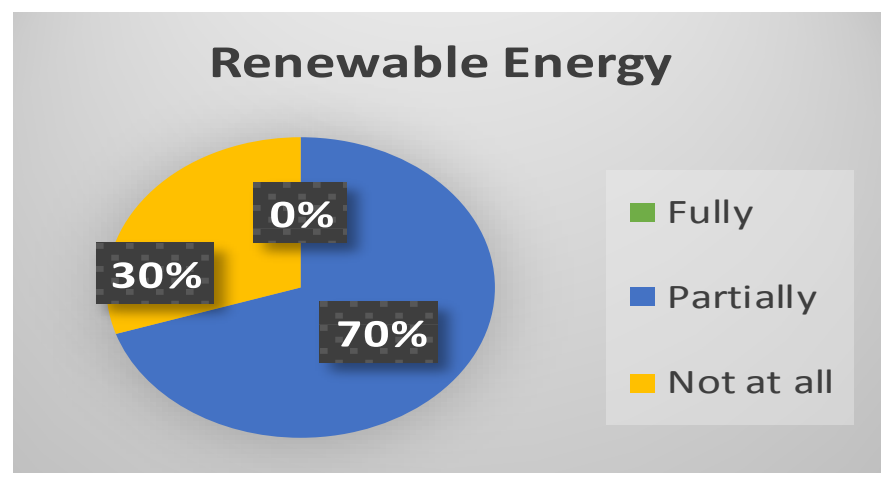

Figure 5. Renewable energy.

\section{Renewable Energy}

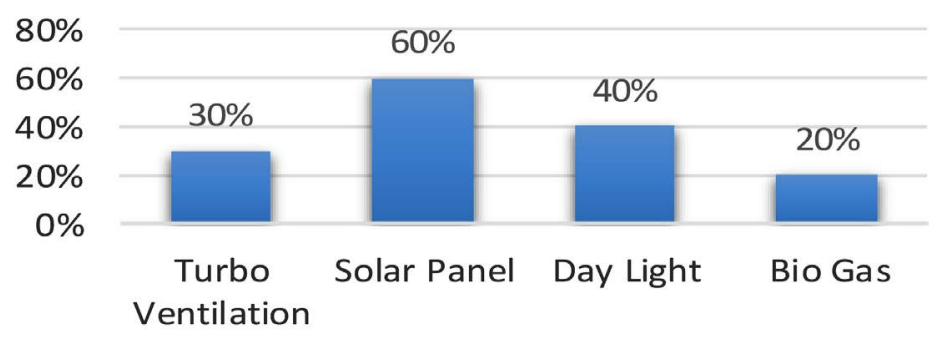

Figure 6. Renewable energy.

\section{Reduction of Water Consumption}

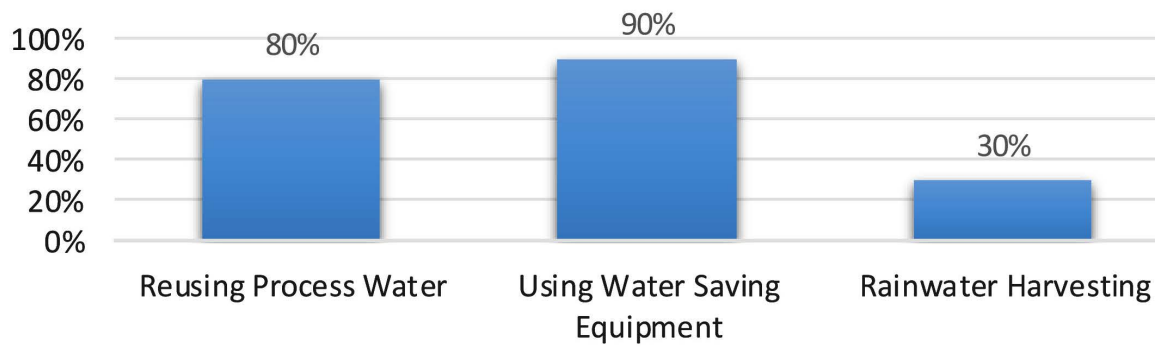

Figure 7. Reduction of water consumption.

In Bangladesh 30\% (3 out of 30) companies used their roof top space or free space as rain water harvesting system to re-use the water for fabric dyeing, washing and other purposes which ultimately reduce ground water usages. 


\subsection{Sustainable Materials}

This section discusses about purchase or use of sustainable raw materials, accessories, non-harmful chemicals, and non-harmful, recyclable and reusable material.

\subsubsection{Sustainable Raw Materials}

"Sustainable raw materials are those components that provide environmental, social and economic benefits while protecting public health and environment over their whole life cycle, from the extraction of raw materials until the final disposal" (Source: Wikipedia). RMG industry of Bangladesh is highly concern about sustainable raw materials because of the concerns of the high-end-brands as customers. The common sustainable raw materials of RMG industry are cotton, organic linen, recycled polyester, and polyamide.

$60 \%$ (6 out of 10 ) companies claimed that they are fully used sustainable raw materials for their production house and rest of $40 \%$ (4 out of 10) companies claimed that they partially use sustainable raw materials, which is showed in Figure 8.

\subsubsection{Recyclable or Reusable Materials (Accessories)}

The other materials of garments except fabric are known as garment accessories. The common garments accessories are buttons, zippers, interlining etc.

$20 \%$ ( 2 out of 10) manufacturers claimed said that they used recyclable or reusable accessories for their production house and $80 \%$ ( 8 out of 10 ) claimed that they are partially fulfil the recyclable accessories, according to Figure 9. But most of the companies said that it depends on buyer's requirements and Bangladesh RMG buyers are concern about sustainability so they usually demand sustainable accessories materials.

\subsubsection{Chemicals Not Harmful to Human Health}

RMG firms need to use chemicals for fabric color and washing of the garments. According to International standard organization like Oeko-tex, a firm should use chemicals that are not harmful to human health.

In Bangladesh, 90\% RMG firms partially procure chemicals that are not harmful to human health. The rest $10 \%$ partially not fulfill the international standards of procuring safe chemicals. Figure 10 showed that data clearly.

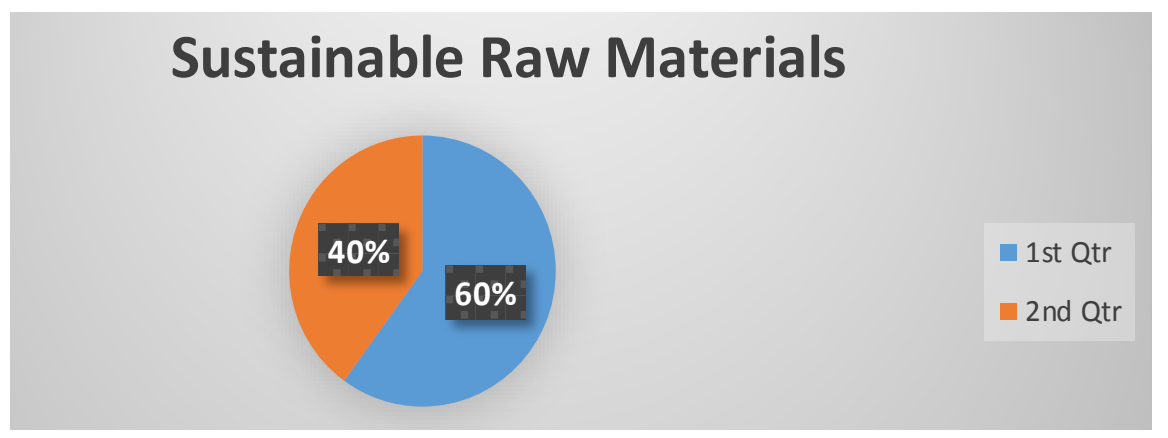

Figure 8. Sustainable raw materials. 


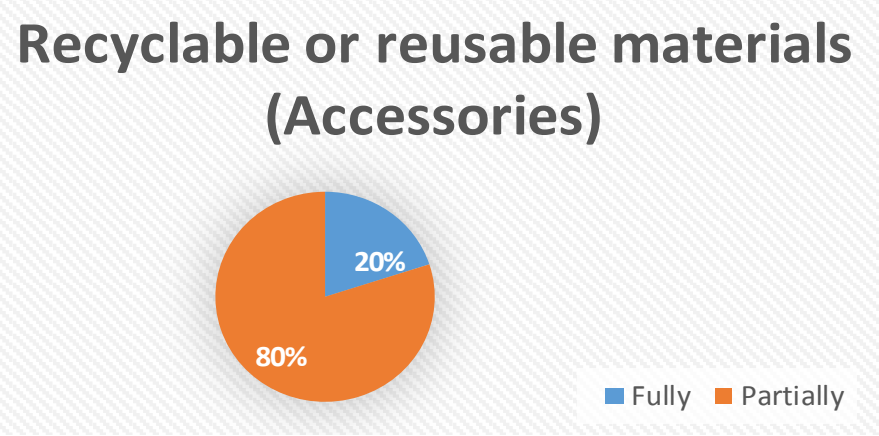

Figure 9. Recyclable or reusable materials.

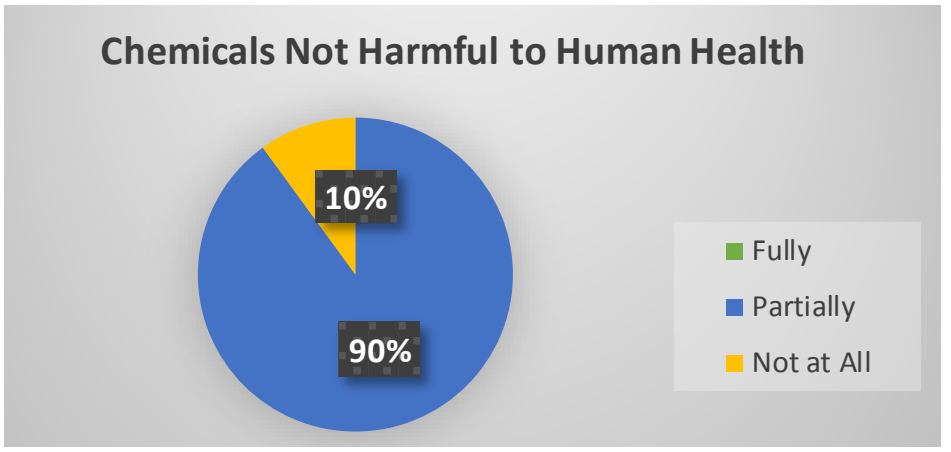

Figure 10. Chemicals not harmful to human health.

\subsubsection{Packaging Materials Not Harmful to Human Health or Recyclable and Reusable}

From Figure 11, we can see that $100 \%$ (10 out of 10 ) companies partially used packing materials which is not harmful for human health or environment and recyclable or reusable like purchasing chemicals with refutable dump, purchase bulk among with refutable container and so on.

\subsection{Benefits of Sustainability}

The many benefits of sustainability are far-reaching. Sustainability maintains the health and bio capacity of the environment. Sustainability supports the well-being of individuals and the thriving of communities. Sustainability promotes a better economy where there is little waste and pollution, fewer emissions, more jobs, and a better distribution of wealth.

Sustainable development is about improving the quality of the economy, not the size of it. The fact is we need a better economy, not a bigger one. Sustainable practices will make the economy better through reduced consumption overall and more equable distribution of wealth. People's lives will be richer through better quality products and services.

Sustainable economies encourage local production over centralized production. Local production has many environmental benefits over centralized, or even offshore, production including reduced emissions, pollution and waste. Localized, smaller-scale production has societal benefits of creating jobs and boosting local economies. 


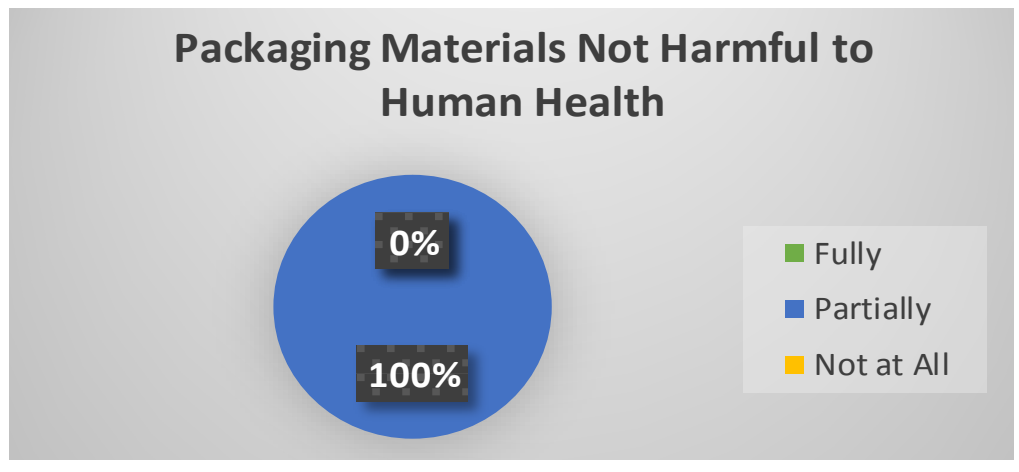

Figure 11. Packaging materials not harmful to human health.

Sustainability encourages a better design as well as less production. This means that products and services will be better quality, more durable and more useful. There will be less junk and less waste.

\subsubsection{Improved Brand Image and Competitive Advantage}

The improvement of brand awareness through "doing good" is becoming one of the pillars of advertising campaigns. In this modern era, people are more conscious about the environment pollution and its effects. In RMG, the business runs globally. The practices of CSR in USA and Europe are high and people are more conscious about the value and impact of CSR in the society, world. And also, sustainability is wanted matters for now a day. Achieving sustainability through CSR in business can give a positive impact for a brand all over the world. This upholds the image of a brand and competitive advantage through promoting sustainability and CSR. People subconsciously happy to pay more while buying a product from a brand which promotes sustainability in production. Because in subconscious mind they know the extra payment is going to serve the society than non-sustainable product brand. And this also attracts people to buy their products and gives competitive advantage. So, achieving sustainability in RMG of Bangladesh can help to build the positive brand image of brand "Made in Bangladesh" and gives a competitive advantage over its competitors.

\subsubsection{Increase Productivity and Reduce Costs}

The development of sustainable business practices lends itself to an efficient operation that streamlines effort and conserves resources, which enhances employee productivity and reduces cost. Reducing cost also encompasses energy conservation strategies that can be as simple as turning off unnecessary lights and insulating walls to more sophisticated efforts such as the installation of geothermal heating and cooling systems. Those efforts having a greater overall impact will likely be more expensive to implement, but the long-term results justify the investment.

\subsubsection{Increase Business Ability to Comply with Regulation}

With all the discussion regarding climate change, dwindling energy resources, 
and environmental impact, it's no surprise that state and federal government agencies are enacting regulations to protect the environment. To integrate sustainability into your business will position it to meet changing regulations in a timely manner.

\subsubsection{Attract Employees and Investors}

In this generation, People like to be associated with the positive, especially younger generations raised on a steady diet of environmental protection messages. They do not want to be linked to companies implicated in ecological disasters and social welfare scandals. To Show your company as respectful of the environment and of its employees, it will attract the caliber of people whom you want to employ and the funds your business needs to expand.

\subsubsection{Reduce Waste}

This is likely the simplest and most obvious way to engage in sustainable practices. Beginning in the 1990s with offices collecting empty cans for recycling, the effort has grown to encompass waste mitigation in paper (conserving trees and forest habitats), value engineering of products (reworking or developing new processes which use less raw materials, waste less material in the production of goods), to changing out incandescent lights for LED lights (greater efficiency combined with fewer bulbs used).

\section{Limitations}

One of the essential obstacles of this have a look at is its small pattern size that is best 10 samples while the whole populace is 4560 BGMEA registered garment factories in Bangladesh. (Source: BGMEA) This isn't always enough to show the overall situation of appropriate sustainable production and development in RMG industry of Bangladesh. Additionally, samples are taken only from those organizations which have at least one global certificate on appropriate manufacturing or related issues that confined this thesis paper to discover applicable facts about suitable manufacturing practices in RMG enterprise.

Additionally, data are amassed inside a brief time frame and interview is taken from the ones companies which situated in Dhaka, Savar and Gazipur that constrained the scope of this thesis. This has a look at entirely works in RMG enterprise but sustainable manufacturing exercise is vital for any industry. This observation could be extended to discover the connection of sustainable production exercise and performance in addition to financial impact inside the industry. Further could be prolonged to comparative evaluation between corporations or industries. But this study is done to find out and uphold the possibilities of achieving sustainability or sustainable development in whole RMG sector of Bangladesh.

This has a look at has been carried out at a very initial level. But appropriate manufacturing and sustainable development are a crucial a part of doing surroundings pleasant commercial enterprise. The government, subsidized with the 
aid of greater studies on this subject be counted, wishes to come forward to encourage and educate the RMG industry to undertake extra sophisticated appropriate.

\section{Conclusion}

Achieving Sustainable Development Goals (SDG's) are a new concern for the RMG industry of Bangladesh. There are few companies that have adopted and implemented this concept within a short period; still there is a huge scope of achieving SDGs in the RMG sector of Bangladesh. Day by day, the scenario is changing keeping pace with the modern era and business culture. The RMG sector starts practicing CSR rapidly. And very few companies have already ensured the positive practice of CSR and through this, they have met few Sustainable Goals and thus achieved sustainability in few fields. There is a huge scope of achieving maximum number of SDGs through positive attitude and CSR practice not only for few companies but also for the whole RMG industry. And by this, the RMG sector of Bangladesh will achieve sustainability that will result in getting competitive advantages in global business over its competitors.

\section{Conflicts of Interest}

The authors declare no conflicts of interest regarding the publication of this paper.

\section{References}

[1] https://www.bgmea.com.bd/home/pages/TradeInformation

[2] Islam, M.S. and Liang, G.Q. (2012) Supply Chain Management on Apparel Order Process: A Case Study in Bangladesh Garment Industry. Asian Journal of Business and Management Sciences, 2, 60-72.

[3] Menzel, A. and Woodruff, C. (2019) Gender Wage Gaps and Worker Mobility: Evidence from the Garment Sector in Bangladesh (No. w25982). National Bureau of Economic Research, Cambridge, MA. https://doi.org/10.3386/w25982

[4] Tauringana, V. (2020) Sustainability Reporting Challenges in Developing Countries: Towards Management Perceptions Research Evidence-Based Practices. Journal of Accounting in Emerging Economies. https://doi.org/10.1108/JAEE-01-2020-0007

[5] Belal, A.R. (2001) A Study of Corporate Social Disclosures in Bangladesh. Managerial Auditing Journal, 16, 274-289. https://doi.org/10.1108/02686900110392922

[6] Alamgir, F. and Banerjee, S.B. (2019) Contested Compliance Regimes in Global Production Networks: Insights from the Bangladesh Garment Industry. Human Relations, 72, 272-297. https://doi.org/10.1177/0018726718760150

[7] Ashraf, H. and Prentice, R. (2019) Beyond Factory Safety: Labor Unions, Militant Protest, and the Accelerated Ambitions of Bangladesh's Export Garment Industry. Dialectical Anthropology, 43, 93-107. https://doi.org/10.1007/s10624-018-9539-0

[8] Masud, A., Hoque, A.A.M., Hossain, M.S. and Hoque, M.R. (2013) Corporate Social Responsibility Practices in Garments Sector of Bangladesh, A Study of Multinational Garments, CSR View in Dhaka EPZ. Developing Country Studies, 3, 27-37.

[9] Ahmed, J.U. and Hossain, T. (2009) Industrial Safety in the Readymade Garment 
Sector: A Developing Country Perspective. Sri Lankan Journal of Management, 14, 1-13.

[10] Islam, S. (2014) The Political Economy of Industrial Accidents in Readymade Garments Factory in Bangladesh: A Case Study of Rana Plaza Tragedy. Doctoral Dissertation, University of Dhaka, Dhaka.

[11] Maç, S.D. and Çalış, Ş. (2011) Labour Practices in the Content of Corporate Social Responsibility: An Evaluation on Automotive Manufacturer Companies' Websites. International Journal of Business and Management Studies, 3, 317-331.

[12] Rupp, D.E., Ganapathi, J., Aguilera, R.V. and Williams, C.A. (2006) Employee Reactions to Corporate Social Responsibility: An Organizational Justice Framework. Journal of Organizational Behavior, 27, 537-543. https://doi.org/10.1002/job.380

[13] Sriramesh, K., Ng, C.W., Ting, S.T. and Wanyin, L. (2007) Corporate Social Responsibility and Public Relations. In: May, S., Cheney, G. and Roper, J., Eds., The Debate over Corporate Social Responsibility, Oxford University Press, USA, 119-134.

[14] Hopkins, M. (2004) Corporate Social Responsibility: An Issues Paper. International Labour Office Working Paper No. 27. https://doi.org/10.2139/ssrn.908181

[15] Carroll, A.B. (1979) A Three-Dimensional Conceptual Model of Corporate Performance. Academy of Management Review, 4, 497-505. https://doi.org/10.5465/amr.1979.4498296

[16] Zerk, J.A. (2006) Multinationals and Corporate Social Responsibility: Limitations and Opportunities in International Law (Vol. 48). Cambridge University Press, Cambridge. https://doi.org/10.1017/CBO9780511494864

[17] Ismail, T.N.T. (2011) Corporate Social Responsibility: The Influence of the Silver Book. International Journal of Business and Management Studies, 3, 371-383.

[18] Khan, M.T., Khan, N.A., Ahmed, S. and Ali, M. (2012) Corporate Social Responsibility (CSR)-Definition, Concepts and Scope. Universal Journal of Management and Social Sciences, 2, 41-52.

[19] Sheokand, D. and Jaswal, R.A. (2016) Intelligence Control of Downdraft Biomass Gasifier Using Fuzzy Logic Controller.

[20] Zohuri, B. (2018) Hybrid Renewable Energy Systems. In: Hybrid Energy Systems, Springer, Cham, 1-38. https://doi.org/10.1007/978-3-319-70721-1_1 